\title{
Analisis Kesehatan Mental Mahasiswa Perguruan Tinggi Pada Awal Terjangkitnya Covid-19 di Indonesia
}

\author{
Aloysius, Suryanto $^{1} *$ dan Salvia, $\mathrm{Nada}^{2}$ \\ ${ }^{I}$ Politeknik Statistika STIS, Indonesia
}

\begin{abstract}
Abstrak--Kesehatan mental merupakan aspek penting dalam kehidupan seseorang. Memiliki kesehatan mental yang baik tidak hanya terhindar dari penyakit mental tetapi juga memiliki keadaan mental yang sejahtera. Mahasiswa berada pada batasan remaja akhir dan dewasa awal, dimana masa ini merupakan masa kondisi mental yang tidak stabil, diiringi dengan konflik dan tuntutan serta perubahan suasana hati. Apabila individu yang mengalami masa tersebut tidak dapat mengontrol hal-hal yang terjadi, maka dapat menimbulkan masalah kesehatan mental yang akan memempengaruhi kesehatannya secara keseluruhan. Selain itu banyak dampak-dampak lain akibat terganggunya kesehatan mental. Oleh karena itu, pentingnya mengakaji lebih jauh mengenai kesehatan mental mahasiswa Perguruan Tinggi X pada awal terjangkitnya Covid-19 di Indonesia dan faktor-faktor yang memengaruhinya. Data yang digunakan dalam penelitian ini adalah data primer yang didapatkan melalui survei kepada mahasiswa Perguruan Tinggi X. Analisis inferensia yang digunakan adalah analisis regresi logistik ordinal. Hasil penelitian ini menunjukkan bahwa sebanyak 46 persen mahasiswa Perguruan Tinggi $\mathrm{X}$ memiliki status kesehatan mental yang buruk. Dari sepuluh variabel penjelas, terdapat empat variabel yang berpengaruh signifikan terhadap kesehatan mental mahasiswa Perguruan Tinggi X tahun akademik 2019/2020 yaitu jenis kelamin, dukungan sosial, ketergantungan smartphone, dan pendapatan.
\end{abstract}

\author{
Kata kunci: \\ Kesehatan Mental, \\ Mahasiswa, \\ Regresi logistic ordinal
}

Histori:

Dikirim: 28 Juni 2021

Direvisi: 20 Agustus 2021

Diterima: 30 September 2021

Online: 30 September 2021

(C)202X JCC. All rights reserved (7) (2) Author(s) agree that this article remains permanently open access under the terms of the Creative Commons Attribution-ShareAlike 4.0 International License

\section{Identitas Artikel:}

Aloysius, A., \& Salvia, N. (2021). Analisis Kesehatan Mental Mahasiswa Perguruan Tinggi Pada Awal Terjangkitnya Covid-19 di Indonesia. Jurnal Citizenship Virtues, 2021, 1(2), 83-97.

\section{PENDAHULUAN}

Pandemi Covid -19 sudah mengkhawatirkan masyarakat internasional. Negara-negara di dunia sudah melarang warga negaranya agar tidak keluar rumah, untuk menghindari terjadinya penularan virus corona. Berdasarkan kebijakan ini, secara tidak langsung telah berpengaruh terhadap polusi udara. Bumi bersih kembali dengan himbauan untuk diam dirumah saja.(Pudjiastuti dan Hadi:2020) Pandemi Covid-19 sangat berpengaruh terhadap kesehatan mental.

Kesehatan mental merupakan aspek utama dalam menentukan kesehatan seorang individu. Definisi kesehatan mental menurut WHO (2013) adalah kondisi

\footnotetext{
$1_{* \text { Corresponding author. }}$

E-mail: suryanto@stis.ac.id
} 
kesejahteraan (well-being) dimana individu dapat merealisasikan kemampuannya sendiri, dapat mengatasi tekanan kehidupan yang normal, dapat bekerja secara produktif, dan mampu memberikan kontribusi kepada komunitasnya. Seseorang memiliki kesehatan mental yang baik tidak hanya terhindar dari penyakit mental tetapi juga memiliki keadaan mental yang sejahtera (Keyes, 2002).

WHO (2001) menyatakan bahwa satu dari empat orang di dunia akan dipengaruhi oleh gangguan mental atau neurologis di beberapa titik dalam kehidupan mereka. Sekitar 450 juta orang saat ini menderita kondisi seperti itu, menempatkan gangguan mental di antara penyebab utama kesehatan buruk dan cacat di seluruh dunia. Salah satu contoh gangguan mental adalah depresi. WHO (2018) menunjukkan bahwa depresi adalah penyakit umum di seluruh dunia, dengan lebih dari 300 juta orang terkena dampaknya.

Di Indonesia, pravelensi depresi pada penduduk umur $>15$ tahun adalah 6,1 persen. Selain itu, prevalensi rumah tangga yang mempunyai anggota rumah tangga yang mengalami gangguan jiwa Skizofrenia/Psikosis adalah sebesar 6,7 persen. (Riskesdas, 2018). Berdasarkan data Riskesdas, dari tahun 2013 ke tahun 2018 pravelensi GME (Gangguan Mental Emosional) kelompok umur 15-24 tahun mengalami peningkatan yang paling signifikan dibanding kelompok umur lainnya.

Rentang umur mahasiswa termasuk ke dalam kelompok umur 15-24 tahun. Menurut teori Erikson (dalam Santrock, 2003), mahasiswa berada pada tahap remaja akhir (adolescence: 10-20 years) dan dewasa awal (early adulthood: 20's and 30's). Rentang usia mahasiswa berada pada batasan remaja akhir dan dewasa awal, dimana masa ini merupakan masa kondisi mental yang tidak stabil, diiringi dengan konflik dan tuntutan serta perubahan suasana hati. Apabila individu yang mengalami masa tersebut tidak dapat mengontrol hal-hal yang terjadi, maka dapat menimbulkan masalah kesehatan mental yang akan memempengaruhi kesehatannya secara keseluruhan.

Penelitian yang dilakukan oleh WHO dalam WHO World Mental Health International College Student project yang meneliti sembilan belas universitas di delapan negara ditemukan bahwa 35 persen mahasiswa seumur hidupnya mengalami setidaknya satu mental disorder DSM-IV yaitu anxiety, mood, atau substance disorder dimana dan 31,4 persen mengalaminya dalam rentang 12 bulan terakhir. Penelitian juga dilakukan oleh Vidiawati (2017) mengenai masalah kesehatan jiwa mahasiswa baru di sebuah universitas di Jakarta. Hasil dari penelitiannya menunjukkan bahwa 12,69 persen mahasiswa mengalami masalah kejiwaan.

Terganggunya kesehatan mental berdampak kepada berbagai aspek kehidupan manusia. Ketika depresi bertahan lama dan dengan intensitas sedang atau berat, depresi dapat menjadi kondisi kesehatan yang serius. Hal ini dapat menyebabkan orang yang terkena sangat menderita dan tidak dapat berfungsi dengan baik di tempat kerja, di sekolah dan di keluarga. Hal terburuknya depresi dapat menyebabkan bunuh diri. Hampir 800.000 orang meninggal karena bunuh diri setiap tahun. Bunuh diri menempati urutan kedua penyebab utama kematian pada usia 15-29 tahun. (WHO, 2018)

Penelitian yang dilakukan Ghozali Rusyid Affandi dan Dewanti Ruparin Diah Fakultas Psikologi Universitas Merdeka Malang 2011 hubungan antara kesehatan mental dan religius sebagai berikut: Hasil uji asumsi mengenai 
normalitas data diperoleh bahwa semua data normal sebagaimana tertera pada table berikut: Kesehatan dengan Zk-s = 0,557, $\mathrm{P}=0,916$ dan Keterangan Normal. Sedang Religiusitas Zk-s $=1,014, \mathrm{P}=0,256$ dan Keterangan Normal. Begitu juga dengan uji linieritas menunjukkan bahwa grafik menunjukkan adanya garis linier karena garis bergerak dari arah kiri bawah ke kanan atas. Berdasarkan tabel korelasi didapatkan bahwa terdapat hubungan antara religiusitas dengan kesehatan mental sebesar (rxy) 0,635 > rtabel $(0,22)$. Hasil uji hipotesis dalam penelitian ini diperoleh F-hitung $=54,068$ dan $\mathrm{p}=0,000$. Dengan taraf kepercayaan 5\% diketahui bahwa F-tabel $=3,96$, maka F-hitung $(54,068)>$ F-tabel $(3,96)$ dan $\mathrm{P}<$ 0,05 yang berarti hiopotesis diterima. Hal ini berarti religiusitas dapat memprediksi kesehatan mental para pemeluk agama Islam. Adapun besar daya prediksinya sebesar $r=0,403$ atau 40,3\%. Tetapi penelitian ini tidak memasukan religius sebab di Perguruan Tinggi $X$ tersebut agama yang dipeluh mahasiswa bermacam-macam maka variabel religious tidak menjadi veriabel penelitian.

Bridge et al. (2006) menyatakan bahwa 80-90 persen remaja yang melakukan bunuh diri atau melakukan percobaan bunuh diri mengalami gangguan mental. Gangguan mental disini mencakup major depression disorder, bipolar disorder, conduct disorder, dan gangguan akan kecanduan zat terlarang (narkoba dan alcohol).

Pada mahasiswa, gangguan kesehatan mental yang dialami dapat berpengaruh terhadap kondisi akademik. Penelitian yang dilakukan Heiligenstein et al. (2015) menyatakan bahwa penurunan nilai akademik sangat sering terjadi pada mahasiswa yang mengidap depresi. Dalam penelitiannya, ditemukan bahwa siswa dengan gangguan akademik, 16 persen mengalami depresi ringan, 43 persen menunjukkan depresi sedang, dan 41 persen mengalami depresi berat.

Dapat disimpulkan bahwa terganggunya kesehatan mental secara langsung maupun tidak langsung akan mempengaruhi kesehatan seseorang yang pada akhirnya akan mempengaruhi aktivitasnya dalam menjalani peran kehidupannya. Dengan adanya kasus-kasus di atas menunjukkan bahwa perlu untuk mengkaji lebih jauh mengenai kondisi kesehatan mental mahasiswa agar dapat mengantisipasi dampak-dampak yang akan merugikan bagi mahasiswa itu sendiri, institusi, keluarga, dan lingkungan sekitar.

Berdasarkan penjabaran di atas, selain melihat bagaimana gambaran kondisi kesehatan mental mahasiswa Perguruan Tinggi $X$, dalam penelitian ini juga akan mengkaji variabel-variabel yang berpotensi memengaruhi kesehatan mental mahasiswa tersebut

Definisi kesehatan mental menurut WHO (2013) adalah kondisi kesejahteraan (well-being) dimana individu dapat merealisasikan kemampuannya sendiri, dapat mengatasi tekanan kehidupan yang normal, dapat bekerja secara produktif, dan mampu memberikan kontribusi kepada komunitasnya.

Daradjat (1968) di dalam bukunya mejelaskan beberapa definisi kesehatan mental

1. Kesehatan mental adalah terhindarnya orang dari gejala-gejala gangguan jiwa (neurose) dan dari gejala-gejala penyakit jiwa (psychose)

2. Kesehatan mental adalah kemampuan untuk menyesuaikan diri dengan diri sendiri, dengan orang lain, dan masyarakat serta lingkungan di mana ia hidup 
3. Kesehatan mental adalah pengetahuan dan perbuatan yang bertujuan untuk mengembangkan dan memanfaatkan segala potensi, bakat, dan pembawaan yang ada semaksimal mungkin, sehingga membawa kepada kebahagiaan diri dan orang lain, serta terhindar dari gangguan-gangguan dan penyakit jiwa

4. Kesehatan mental adalah terwujudnya keharmonisan yang sungguh-sungguh antara fungsi-fungsi jiwa, serta mempunyai kesanggupan untuk menghadapi problem-problem biasa yang terjadi, dan merasakan secara positif kebahagiaan dan kemampuan dirinya

Keyes (2002) yang menyatakan bahwa kesehatan mental tidak hanya tidak adanya penyakit mental tetapi juga keadaan mental yang sejahtera. Sejalan dengan pernyataan di atas, Veit dan Ware (1983) mengemukakan bahwa mental yang sejahtera mencakup dua aspek, aspek pertama yaitu terbebasnya individu dari tekanan psikologi (psychological distress) yang dicirikan dengan tingginya tingkat kecemasan, depresi dan kehilangan kontrol; aspek kedua yaitu terdapatnya kesejahteraan psikologi (psychological well-being) yang dicirikan dengan adanya perasaan positif secara umum, kondisi emosional dan kepuasan hidup.

Kesehatan mental ditentukan oleh faktor biologis, psikologis, sosial, ekonomi, religiusitas, dan lingkungan yang berinteraksi dalam cara yang kompleks (Mrazek \& Haggerty, 1994; Rogers \& Pilgrim, 2005). Demografi seperti usia, jenis kelamin, dan etnis adalah faktor penentu penting yang memengaruhi paparan risiko dan faktor perlindungan di seluruh siklus hidup. Menurut Daradjat (2001), faktor-faktor yang mempengaruhi kesehatan mental itu secara garis besar ada dua yaitu faktor internal dan eksternal. Faktor internal ini antara lain meliputi: kepribadian, kondisi fisik, perkembangan dan kematangan, kondisi psikologis, keberagamaan/religius, sikap menghadapi problema hidup, kebermaknaan hidup, dan keseimbangan dalam berfikir. Adapun yang termasuk faktor eksternal antara lain: keadaan sosial, ekonomi, politik, adat kebiasaan, lingkungan, dan sebagainya.

Notosoedirdjo dan Latipun (2005) menyatakan kesehatan mental merupakan entitas yang dipengaruhi oleh beberapa faktor baik internal maupun eksternal. Kesehatan mental sangat dipengaruhi factor-faktor tersebut, karena secara subtantif faktor-faktor tersebut memainkan peran yang signifikan dalam terciptanya kesehatan mental. Yang termasuk faktor internal adalah faktor biologis dan psikologis, sedangkan yang termasuk faktor eksternal adalah sosial budaya.

Faktor eksternal juga merupakan faktor yang tidak kalah penting dalam mempengaruhi kesehatan mental seseorang, diantarnya adalah stratifikasi sosial, interaksi sosial, lingkungan baik lingkungan keluarga, sekolah dan masyarakat yang diadalamnya juga terkandung lingkungan tempat tinggal yang ia diami atau tempati (Muhyani, 2012:51). Jadi kesehatan mental itu dipengarui oleh faktor dalam dan luar diri seseorang sehingga keduanya mempunyai posisi yang sangat kuat dalam kehidupan manusia. 


\section{METODE PENELITIAN}

Penelitian dilakukan kepada mahasiswa Perguruan Tinggi $X$ tahun akademik 2019/2020. Data yang digunakan dalam penelitian ini adalah data primer yang dikumpulkan menggunakan instrument penelitian berupa kuesioner. Sebelum dilaksanakan penelitian sebenarnya, terlebih dahulu dilakukan penelitian pendahuluan pada tanggal 23 - 27 Maret 2020 yang digunakan untuk uji validitas dan reliabilitas kuesioner. Penelitian sebenarnya dilakukan pada tanggal 13-19 April 2020. Baik penelitian pendahuluan maupun sebenarnya dilakukan saat PJJ (Perkuliahan Jarak Jauh) berlangsung.

Populasi penelitian ini adalah seluruh mahasiswa Perguruan Tinggi X tahun akademik 2019/2020 yang berjumlah 2201 mahasiswa. Kerangka sampel yang digunakan sebagai dasar penarikan sampel merupakan daftar absensi mahasiswa Perguruan Tinggi X tahun akademik 2019/2020 yang diperoleh dari Bagian Kemahasiswaan nya. Sampel terpilih ini didapatkan dengan menggunakan metode circular systematic sampling. Sebelum menarik sampel, populasi mahasiswa Perguruan Tinggi X dikategorikan ke dalam empat strata berdasarkan tingkat, yaitu tingkat I, II, III, dan IV. Penentuan banyaknya jumlah sampel menggunakan metode penentuan sampel minimum Cochran (Cochran, 1977). Berdasarkan rumus tersebut, didapatkan minimum sampel pada penelitian ini sebesar 327 mahasiswa. Untuk mengantisipasi non respons, peneliti menambah sampel sehingga menjadi 350 mahasiswa.

Metode analisis yang digunakan dalam penelitian ini adalah analisis deskriptif dan analisis inferensia. (Pudjiastuti:2019) Analisis deskriptif dilakukan untuk memberikan gambaran umum mengenai kesehatan mental mahasiswa Perguruan Tinggi X tahun akademik 2019/2020 yang disajikan dalam bentuk diagram. Analisis inferensia yang digunakan dalam penelitian ini menggunakan analisis regresi logistic ordinal dimana hasil dari analisis ini nantinya akan diketahui variabel apa-apa saja yang memengaruhi status kesehatan mental mahasiswa Perguruan Tinggi X tahun akademik 2019/2020. Adapun langkahlangkah dalam analisis resgresi logistik ordinal adalah sebagai berikut :

1. Pengujian asumsi parallel lines

2. Pengujian kesesuaian model

3. Pengujian parameter secara simultan

4. Pengujian parameter secara parsial

5. Pembentukan model

6. Perhitungan Odds Ratio

HASIL DAN PEMBAHASAN Kesehatan Mental 


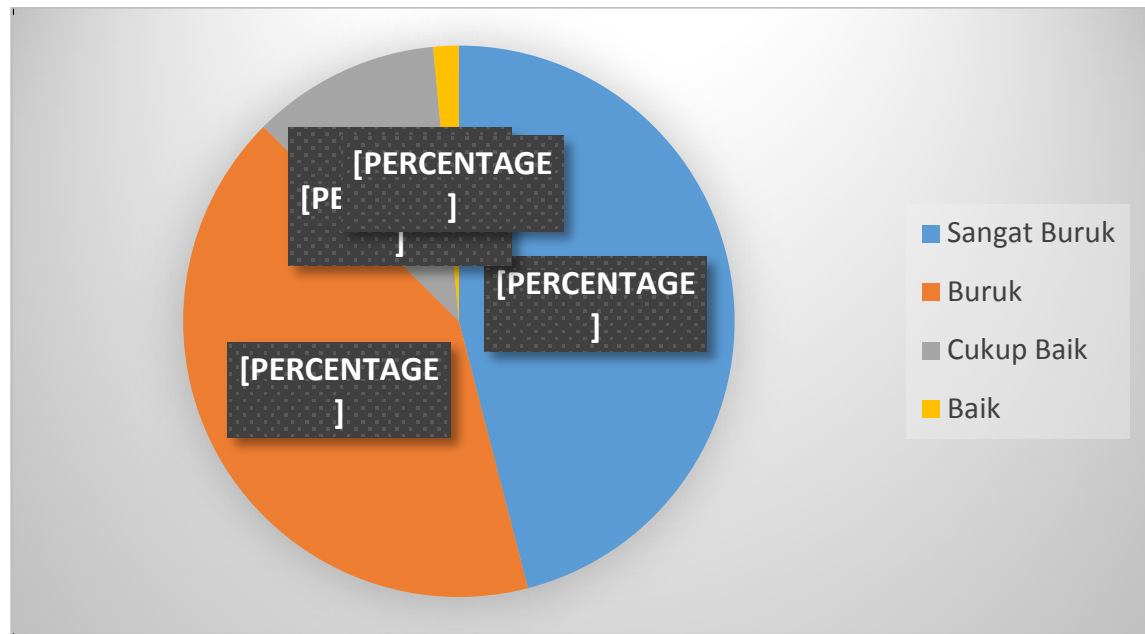

Gambar 1. Persentase mahasiswa Perguruan Tinggi X tahun akademik 2019/2020 menurut status Kesehatan mental

Gambar 1 menunjukkan bahwa 46 persen mahasiswa Perguruan Tinggi X memiliki kesehatan mental yang sangat buruk dan 41 persen memiliki Kesehatan mental yang buruk. Sebanyak 11 persen memiliki kesehatan mental yang cukup baik dan hanya 2 persen mahasiswa memiliki Kesehatan mental yang baik. Pada penelitian ini, tidak ditemukan mahasiswa yang memilki status kesehatan mental yang sangat baik.

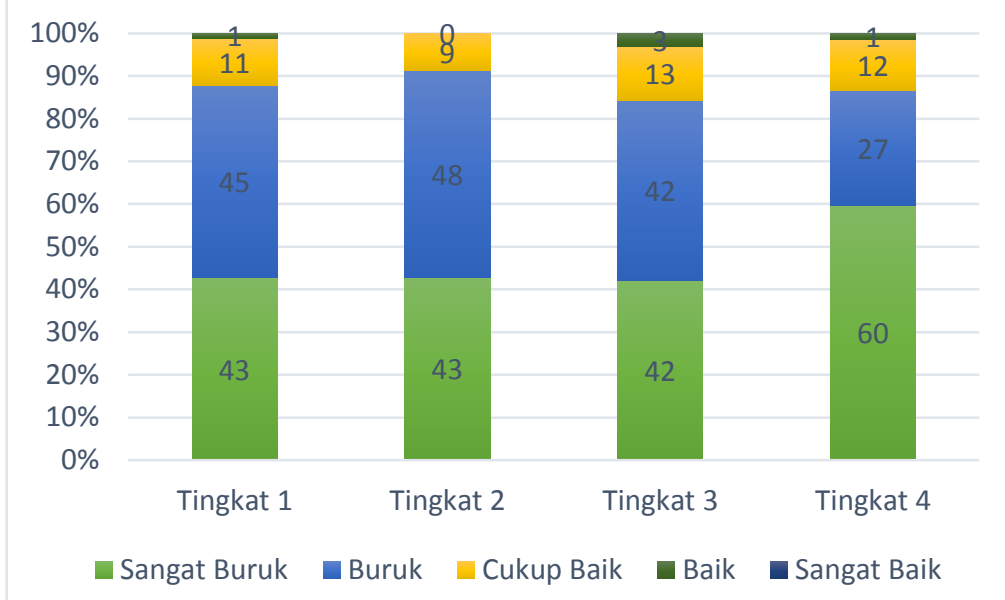

Gambar 2. Persentase mahasiswa Perguruan Tinggi X tahun akademik 2019/2020 menurut status Kesehatan mental pada setiap tingkat

Gambar 2 menunjukkan persentase status kesehatan mental mahasiswa Perguruan Tinggi $X$ tiap tingkat. Dari gambar tersebut dapat kita ketahui bahwa dari seluruh tingkat, tingkat IV memiliki persentase tertinggi mahasiswa dengan status kesehatan mental yang sangat buruk. Persentase tertinggi status kesehatan mental yang buruk adalah tingkat II. Dibanding ketiga tingkat lainnya, tingkat III memiliki persentase tertinggi pada status kesehatan mental yang cukup baik dan baik. 


\section{Jenis Kelamin}

Gambar 3 menunjukkan bahwa dalam penelitian ini persentase mahasiswa lakilaki dan perempuan memilki proporsi yang hampir sebanding. Hal ini dapat mendukung hasil analisis deskriptif untuk melihat gambaran status kesehatan mental mahasiswa berdasarkan jenis kelamin yang representative.

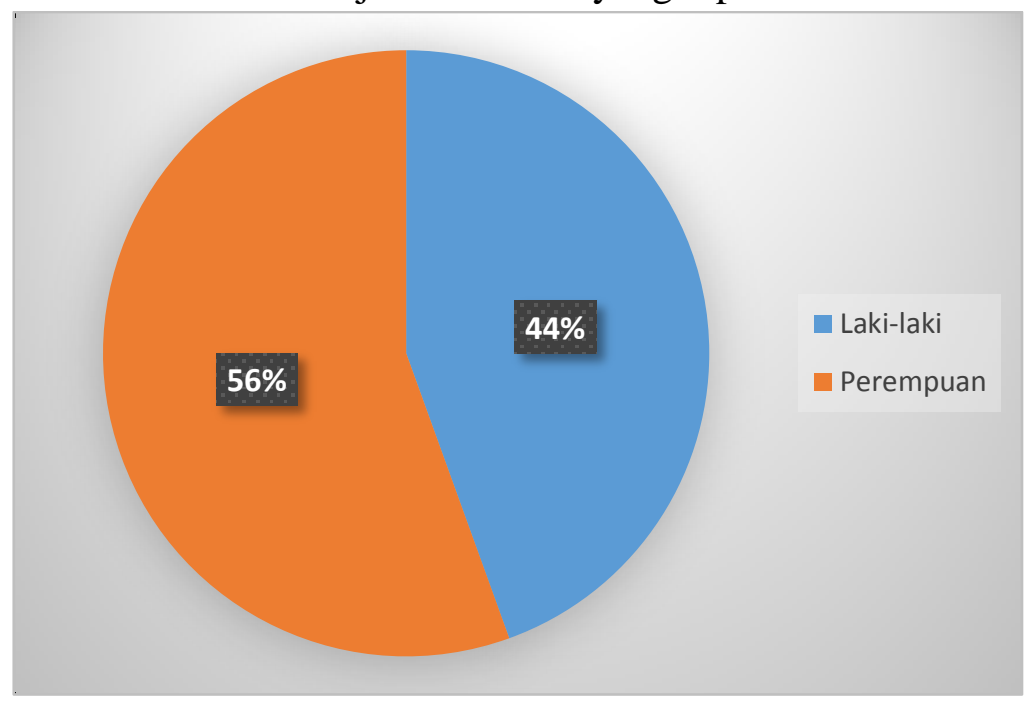

Gambar 3. Persentase mahasiswa Perguruan Tinggi X berdasarkan jenis kelamin

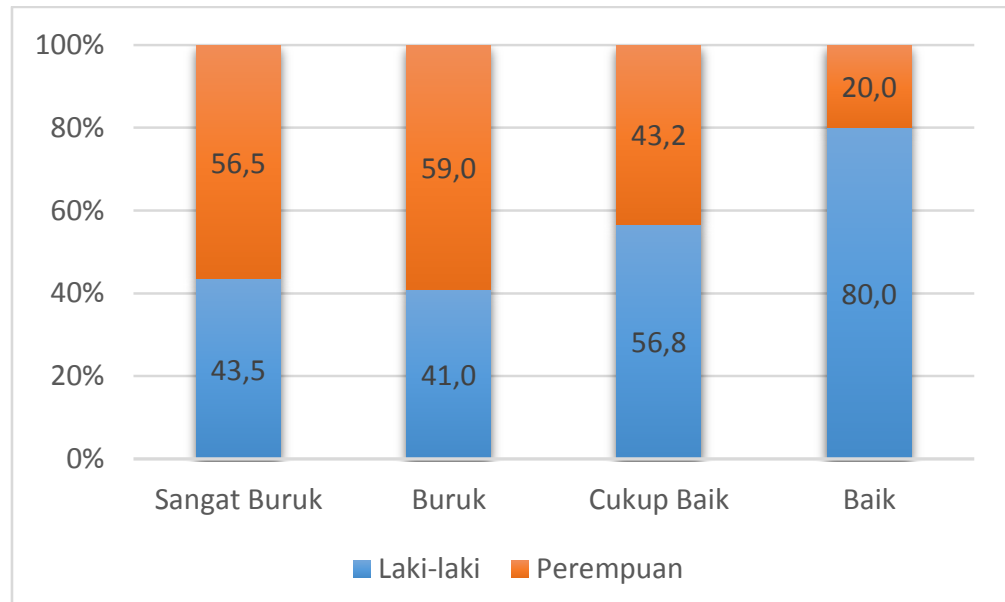

Gambar 4. Persentase mahasiswa Perguruan Tinggi X berdasarkan jenis kelamin dan status kesehatan mental

Dalam penelitian ini didapatkan bahwa perempuan cenderung kesehatan mental yang buruk maupun sangat buruk. Pada status kesehatan mental yang cukup baik dan baik, persentase laki-laki lebih tinggi dari perempuan. Hal ini sejalan dengan penelitian Selima (2010) yang menunjukkan bahwa perkembangan emosional remaja perempuan lebih terganggu dibandingkan dengan remaja lakilaki. 


\section{Dukungan Sosial}

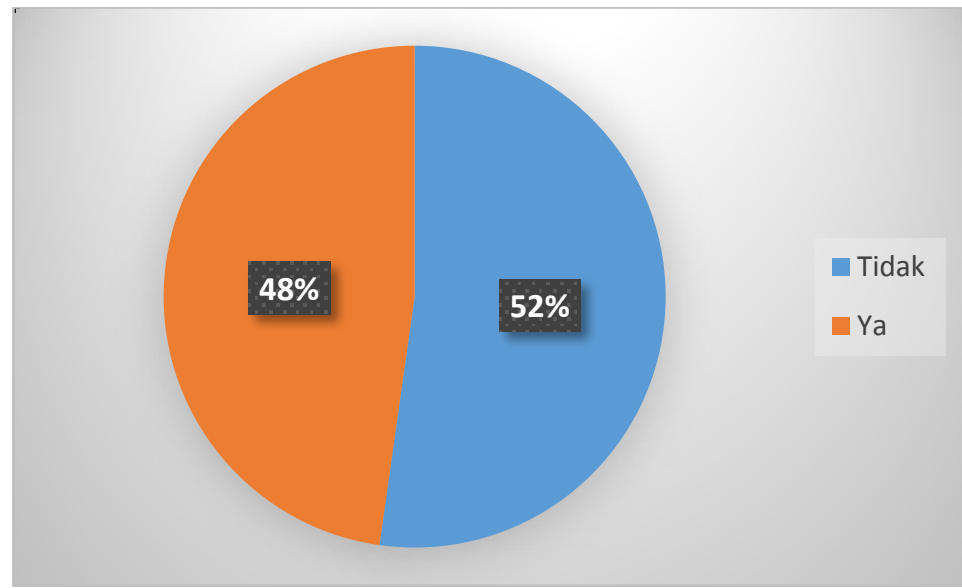

Gambar 5. Persentase mahasiswa Perguruan Tinggi X berdasarkan dukungan social

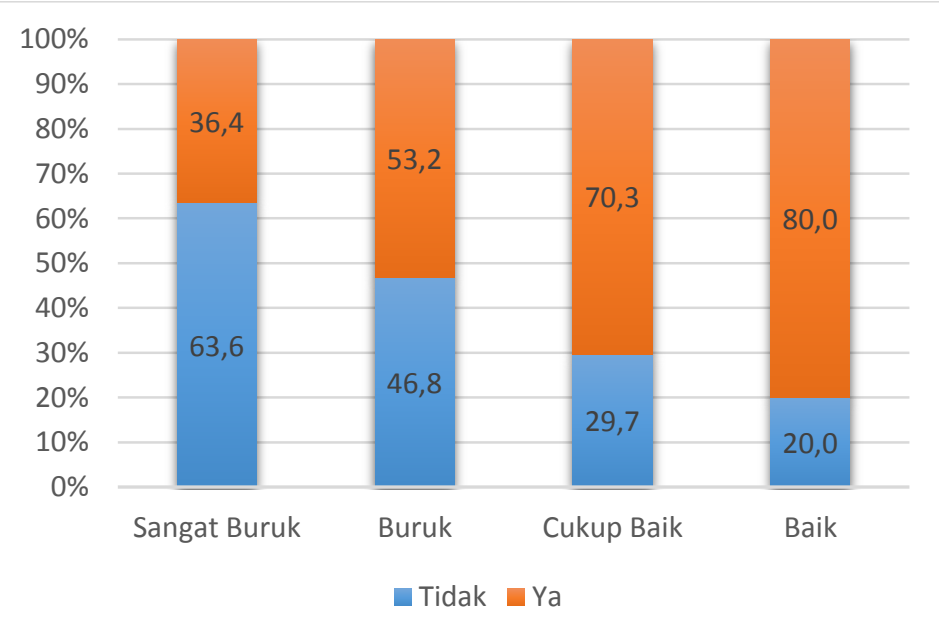

Gambar 6 Persentase mahasiswa Perguruan Tinggi X berdasarkan dukungan sosial dan status kesehatan mental

Gambar 5. menunjukkan bahwa persentase mahasiswa yang mendapatkan dukungan sosial dengan yang tidak mendapatkan hampir seimbang. Keterangan lebih lanjut ditunjukkan oleh Gambar 4.6 bahwa semakin baik status kesehatan mental semakin tinggi persentase mahasiswa yang mendapatkan dukungan sosial. Hal ini sejalan dengan penelitian yang dilakukan oleh Bovier et al (2004) bahwa dukungan sosial berasosiasi positif dengan kesehatan mental. 


\section{Ketergantungan Smartphone}

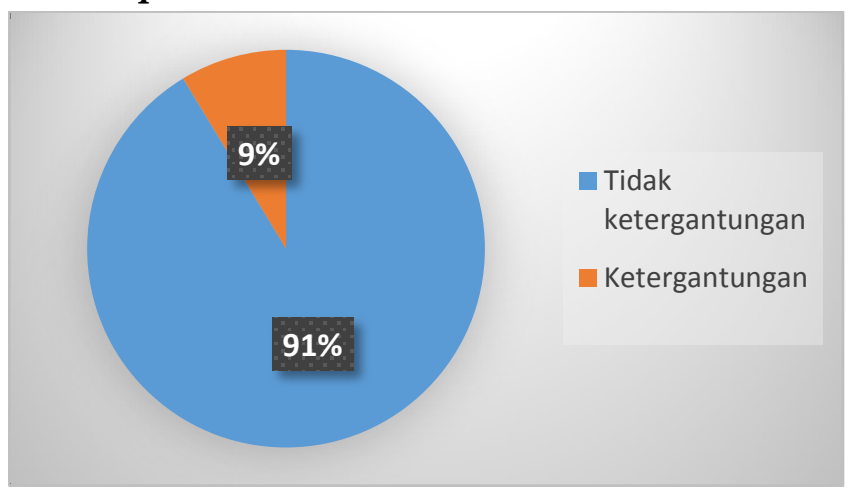

Gambar 7. Persentase mahasiswa Perguruan Tinggi X berdasarkan status ketergantungan smartphone

Gambar 7 menunjukkan bahwa Sebagian besar mahasiswa Perguruan Tinggi X tidak mengalami ketergantungan akan smartphone. Hanya 9 persen mahasiswa yang mengalami ketergantungan smartphone. Pada gambar 4.8 dapat kita ketahui bahwa semakin baik status kesehatan mental semakin rendah persentase mahasiswa yang ketergantungan smartphone.

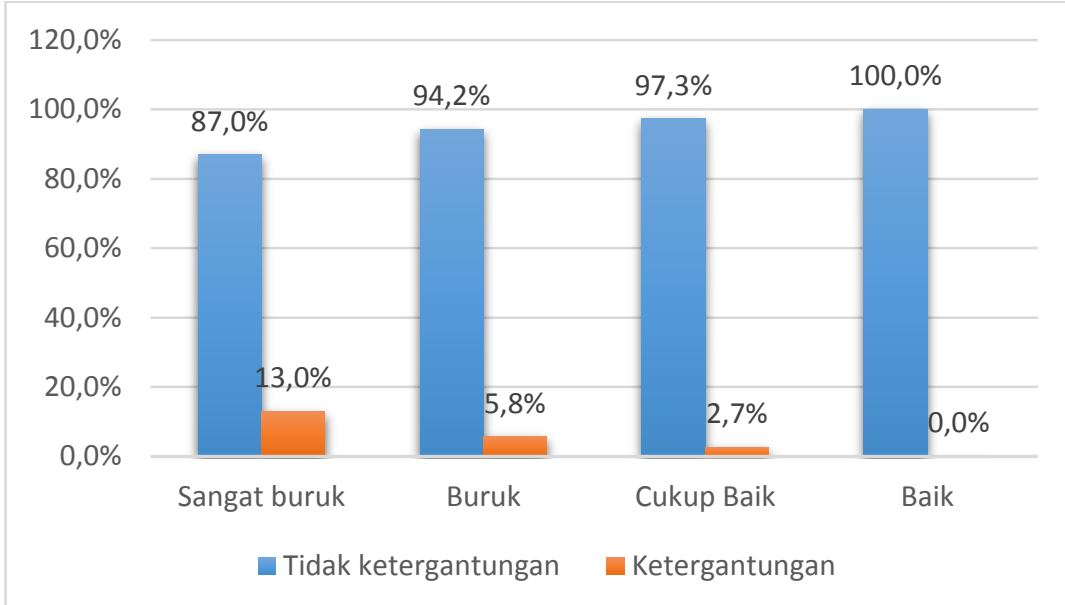

Gambar 8. Persentase mahasiswa Perguruan Tinggi X berdasarkan kesehatan mental dan ketegantungan smartphone

\section{Pelecehan Seksual}




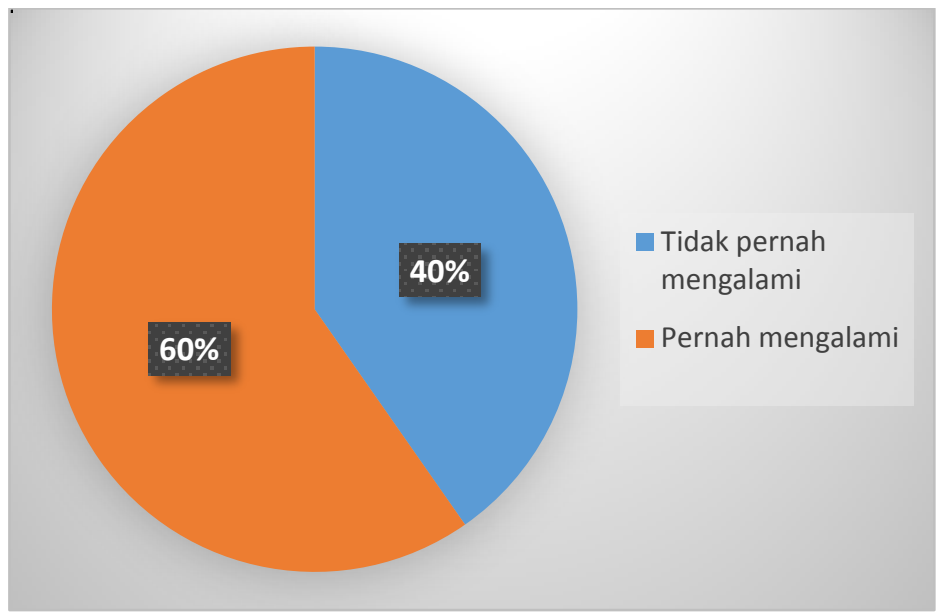

Gambar 9. Persentase mahasiswa Perguruan Tinggi X berdasarkan pengalaman mengalami pelecehan seksual

Pelecehan seksual dalam penelitian ini meliputi pelecehan fisik, lisan, nonverbal/isyarat, visual, dan atau psikologis/emosional. Gambar 4.9 menunjukkan persentase mahasiswa yang pernah mengalami pelecehan seksual, apapun jenis pelecehan yang dialami. Sebanyak 60 persen mahasiswa pernah mengalami setidaknya salah satu dari lima jenis pelecehan seksual tersebut.

\section{Kekerasan Dalam Rumah Tangga}

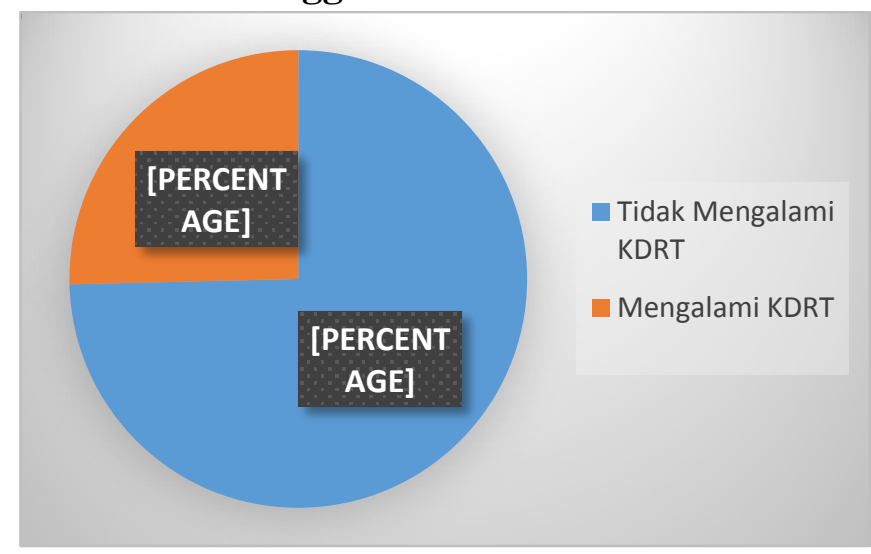

Gambar 10. Persentase mahasiswa Perguruan Tinggi X berdasarkan pengalaman mengalami kekerasan dalam rumah tangga

Kekarasan dalam rumah tangga mencakup kekerasan fisik, kekerasan psikis,kekerasan seksual, dan penelantaran yang dilakukan oleh anggota dalam rumah tangga terhadap responden. Gambar 4.10 menunjukkan sebanyak 25 persen dari responden pernah mengalami satidaknya salah satu dari keempat jenis kekerasan dalam rumah tangga. Kaitannya dengan kesehatan mental ditunjukkan pada Gambar 4.11. Pada gambar tersebut dapat diketahui bahwa semakin baik tingkatan status kesehatan mental maka semakin sedikit persentase responden yang pernah mengalami KDRT. 


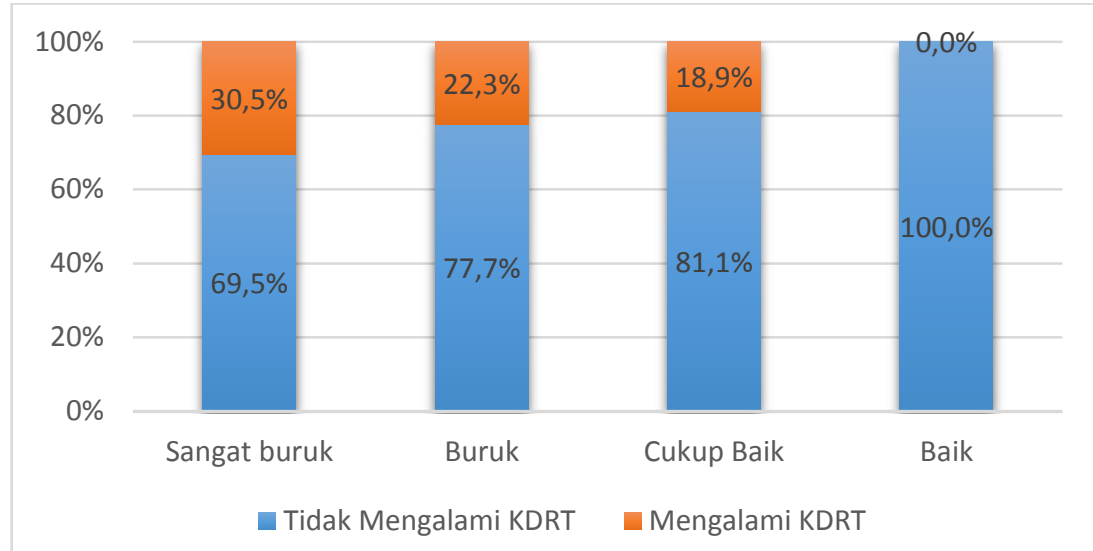

Gambar 11. Persentase mahasiswa Perguruan Tinggi X berdasarkan kesehatan mental dan pengalaman mengalami kekerasan dalam rumah tangga

\section{Asumsi Parallel Lines}

Tabel 1. Test of Parallel Lines

\begin{tabular}{lcrrr}
\hline Model & -2 Log Likelihood & Chi-Square & df & Sig \\
\hline $\begin{array}{l}\text { Null Hypothesis } \\
\text { General }\end{array}$ & 382.817 & & & \\
\hline
\end{tabular}

Dilihat dari nilai signifikansi 0,407 > 0,005, hasil uji asumsi parallel lines menunjukkan gagal tolak $\mathrm{H}_{0}$ yang berarti slope pada setiap kategori sama sehingga model proportional odds dapat digunakan

\section{Uji Kesesuaian Model (Goodness of Fit)}

Tabel 2. Goodness of fit

\begin{tabular}{lccc}
\hline Statistik Uji & Chi-Square & df & Sig. \\
\hline$(1)$ & $(2)$ & $(3)$ & $(4)$ \\
\hline Pearson & 269.376 & 377 & 1.000 \\
Deviance & 270.402 & 377 & 1.000
\end{tabular}

Output dari goodness of fit test menunjukkan kesesuaian model dengan data. P-value bernilai lebih dari 0,05 sehingga keputusan yang diambil adalah gagal tolak $\mathrm{H}_{0}$. Hal ini berarti model yang digunakan sesuai dengan data.

\section{Uji Simultan}

Tabel 3. Hasil uji simultan 


\begin{tabular}{lcccc}
\hline Model & -2 Log Likelihood & Chi-Square & df & Sig. \\
\hline$(1)$ & $(2)$ & $(3)$ & $(4)$ & $(5)$ \\
\hline Intercept Only & 434.717 & & & \\
\hline Final & 382.817 & 51.899 & 10 & 0.000
\end{tabular}

Dari hasil di atas, dapat diketahui bahwa p-value sebesar 0,000. Maka keputusan yang diambil adalah tolak $\mathrm{H}_{0}$. Hal ini berarti dengan tingkat kepercayaan 95 persen dapat dikatakan bahwa minimal terdapat satu variabel bebas yang memengaruhi variabel status kesehatan mental.

\section{Uji Parsial}

Pengujian ini digunakan untuk mengetahui variabel-variabel independent yang berpengaruh terhadap variabel dependen. Hipotesis nul dalam pengujian ini adalah tidak ada pengaruh suatu variabel independent ke-j terhadap variabel dependen. Jika hipotesis nul ditolak, maka dapat dikatakan ada pengaruh suatu variabel independen ke-j terhadap status kesehatan mental dengan $\mathrm{j}$ adalah banyaknya variabel dalam penelitian ini.

Tabel 4. Penduga parameter regresi logistik ordinal dan signifikansinya

\begin{tabular}{|c|c|c|c|c|}
\hline Variabel & Estimate & Std. Error & Wald & Sig. \\
\hline (1) & (2) & (3) & (4) & (5) \\
\hline Intercept 1 & 0.379 & .647 & 0.342 & 0.559 \\
\hline Intercept 2 & 2.720 & .663 & 16.838 & 0.000 \\
\hline Intercept 3 & 5.042 & .784 & 41.838 & 0.000 \\
\hline $\begin{array}{l}\text { Jenis Kelamin } \\
\text { (X1) }\end{array}$ & -0.738 & .245 & 9.044 & $0.003^{*}$ \\
\hline $\begin{array}{l}\text { Dukungan Sosial } \\
\text { (X2) }\end{array}$ & 0.947 & .228 & 17.212 & $0.000 *$ \\
\hline $\begin{array}{l}\text { Ketergantungan } \\
\text { Smartphone (X3) }\end{array}$ & -1.026 & .436 & 5.529 & $0.019^{*}$ \\
\hline $\begin{array}{l}\text { Pengalaman } \\
\text { Pelecehan } \\
\text { Seksual (X4) }\end{array}$ & -0.302 & .271 & 1.755 & 0.185 \\
\hline $\begin{array}{l}\text { Pengalaman } \\
\text { KDRT (X5) }\end{array}$ & -0.422 & .271 & 2.413 & 0.120 \\
\hline $\begin{array}{l}\text { Jenis Kelamin } \\
\text { KRT (X6) }\end{array}$ & 0.627 & .354 & 3.135 & 0.077 \\
\hline Status Bekerja & -0.086 & .368 & 0.055 & 0.815 \\
\hline
\end{tabular}




\begin{tabular}{lcccc} 
KRT (X7) & & & & \\
\hline Jenis Wilayah & 0.082 & .223 & 1.36 & 0.712 \\
Daerah Asal (X8) & & & & \\
Pendidikan KRT & -0.421 & .312 & 1.817 & 0.178 \\
$(X 9)$ & & & & \\
\hline $\begin{array}{l}\text { Pendapatan } \\
(X 10)\end{array}$ & 1.142 & .338 & 11.442 & $0.001^{*}$ \\
\hline
\end{tabular}

Keterangan : *) signifikan pada tingkat kepercayaan 95\%

Hasil dari pengujian parsial pada model menunjukkan bahwa variabel penjelas yang signifikan terhadap status kesehatan mental adalah variabel jenis kelamin, dukungan sosial, ketergantungan smartphone, dan pendapatan. Hal ini dapat dilihat dari nilai p-value variabel-variabel tersebut kurang dari 0,05. Artinya variabel jenis kelamin, dukungan sosial, ketergantungan smartphone, dan pendapatan pada tingkat kepercayaan 95 persen dapat dinyatakan berpengaruh secara signifikan terhadap status kesehatan mental mahasiswa Politeknik Statistika STIS tahun akademik 2019/2020.

Berdasarkan nilai penduga parameter di atas, dapat dibuat model analisis regresi logistik ordinal sebagai berikut

Model regresi logistik status kesehatan mental sangat buruk

$$
\begin{aligned}
\ln \left(\frac{P(Y \leq 0)}{P(Y>0)}\right) & \\
& =0,379-0,738 X_{1} *+0,947 X_{2} *-1,026 X_{3} *-0,302 X_{4} \\
& -0,422 X_{5}+0,627 X_{6}-0,086 X_{7}+0,082 X_{8}-0,421 X_{9} \\
& +1,142 X_{10} *
\end{aligned}
$$

Model regresi logistik status kesehatan mental buruk

$$
\begin{aligned}
\ln \left(\frac{P(Y \leq 1)}{P(Y>1)}\right) & \\
& =2,72-0,738 X_{1} *+0,947 X_{2} *-1,026 X_{3} *-0,302 X_{4} \\
& -0,422 X_{5}+0,627 X_{6}-0,086 X_{7}+0,082 X_{8}-0,421 X_{9} \\
& +1,142 X_{10} *
\end{aligned}
$$

Model regresi logistik status kesehatan mental cukup baik

$$
\ln \left(\frac{P(Y \leq 2)}{P(Y>2)}\right)
$$

$$
\begin{aligned}
& =5,042-0,738 X_{1} *+0,947 X_{2} *-1,026 X_{3} *-0,302 X_{4} \\
& -0,422 X_{5}+0,627 X_{6}-0,086 X_{7}+0,082 X_{8}-0,421 X_{9} \\
& +1,142 X_{10} *
\end{aligned}
$$

Keterangan : *) signifikan pada tingkat kepercayaan $95 \%$

\section{Rasio Kecenderungan (Odds Ratio)}


Pengujian ini digunakan untuk mengetahui kecenderungan variabel bebas terhadap variabel terikat. Selain itu odds ratio dapat digunakan untuk menginterpretasi koefisen dari regresi logistik ordinal.

Tabel 5. Rasio kecenderungan

\begin{tabular}{ccc}
\hline Variabel & $\hat{\beta}$ & $e^{\beta}$ \\
\hline$(1)$ & $(2)$ & $(3)$ \\
\hline Jenis Kelamin & $-0,738$ & 0,47807 \\
\hline Dukungan Sosial & 0,947 & 2,57796 \\
\hline Ketergantungan & $-1,026$ & 0,35844 \\
Smartphone & & \\
\hline Pendapatan & 1,142 & 3,13303 \\
\hline
\end{tabular}

\section{KESIMPULAN}

Berdasarkan hasil dan pembahasan, maka peneliti memperoleh kesimpulan sebagai berikut :

1. Secara umum mahasiswa Perguruan Tinggi X tahun akademik 2019/2020 cenderung memiliki kesehatan mental yang tidak baik dibuktikan dengan persentase mahasiswa yang memiliki kesehatan mental yang sangat buruk sebesar 46 persen dan kesehatan mental yang buruk sebesar 41 persen. Hal ini akibat pengaruh awal-awal terjadinya Covid-19 sehingga kondisi mental mahasiswa turun dratis.

2. Variabel yang berpengaruh signifikan terhadap status kesehatan mental mahasiswa Perguruan Tinggi X tahun akademik 2019/2020 meliputi jenis kelamin, dukungan sosial, ketergantungan smartphone, dan pendapatan.

3. Berdasarkan variabel-variabel yang berpengaruh secara signifikan, mahasiswa berjenis kelamin perempuan, tidak mendapatkan dukungan sosial, ketergantungan smartphone, dan pendapatan di bawah $\mathrm{Rp}$ 1.000.000,00, cenderung memiliki status kesehatan yang lebih buruk.

\section{REFERENSI}

Agresti, A. (2003). Categorical data analysis (Vol. 482). John Wiley \& Sons. Auerbach, R. P., Mortier, P., Bruffaerts, R., Alonso, J., Benjet, C., Cuijpers, P., ... \& Kessler, R. C. (2018). WHO world mental health surveys international college student project: prevalence and distribution of mental disorders. Journal of abnormal psychology, 127(7), 623.

Kesehatan, K. (2018). Hasil Utama Riskesdas 2018. Jakarta: Kementrian Kesehatan.

Keyes, C. L. (2002). The mental health continuum: From languishing to flourishing in life. Journal of health and social behavior, 207-222.

Pudjiastuti, S. R. (2006). Metode Penelitian Pendidikan. Media Akademi

Pudjiastuti, S. R., \& Hadi, N. (2020). The Effect of Corona Virus on the Global Climate. JHSS (Journal of Humanities and Social Studies), 4(2), 130-136. Santrock, J. W. (2001). 8th Edition Adolescene. New York: McGrow-Hill. 
Analisis Kesehatan Mental Mahasiswa ...

Veit, Ware. (1983). The Structure of Psychological Distress and Well-Being ini General Population. Journal of Consulting and Clinical Psychology, 720-742.

WHO. (2013). Mental Health Action Plan 2013-2020. Geneva: World Health Organization. 